\title{
Prevalence of the MTHFR C677T Mutation in Fertile and Infertile Women
}

\section{Prevalência da mutação MTHFR C677T em mulheres férteis e inférteis}

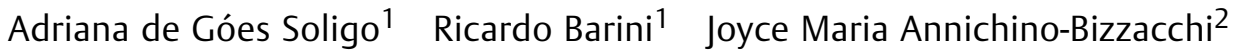 \\ ${ }^{1}$ Department of Tocogynecology, Universidade Estadual de \\ Campinas, Campinas, São Paulo, Brazil \\ 2 Department of Hematology, Universidade Estadual de Campinas, \\ Campinas, São Paulo, Brazil \\ Address for correspondence Adriana de Góes Soligo, MD, \\ Departmento de Tocoginecologia, Universidade Estadual de \\ Campinas, Avenida Jurema, 200, apto 14B, Moema, Campinas, SP, \\ 04079-000, Brazil (e-mail: contato@adrianadegoes.com.br).
}

Rev Bras Ginecol Obstet 2017;39:659-662.

\begin{abstract}
Keywords

- infertility

- thrombophilia

- MTHFR C677T mutation
\end{abstract}

\section{Resumo}

Introduction The importance of the C677T mutation in the methylenetetrahydrofolate reductase (MTHFR) gene in infertile women remains controversial.

Objective To evaluate if the MTHFR C677T mutations are more frequent in infertile women, and if they can be associated with the occurrence of infertility in the Brazilian population.

Methods This case-control study included 130 infertile women consulting at a private clinic between March 2003 and March 2005 (data previously published), and 260 fertile women attending the family planning outpatient clinic of our institution between April 2012 and March 2013.

Data analysis The Chi-squared and Fisher Exact tests were used to evaluate the association between the presence of the MTHFR C677T mutation and a history of infertility.

Results The frequency of the mutation was of $58.5 \%$ for the case group $(n=76)$ and of $49.2 \%$ for the fertile controls $(n=128)$. The mutation was homozygous in 13 women in the case group (10\%) and in 23 of the fertile women in the control group (8.8\%). These differences were not statistically significant.

Conclusions These results suggest that the presence of the MTHFR C677T mutation does not constitute a risk factor for infertility, even when the mutation is homozygous. Further studies are needed to confirm whether research on this mutation should be considered unnecessary in women with infertility.

Introdução A importância da mutação C677T no gene da metilenotetrahidrofolato redutase (MTHFR) em mulheres com infertilidade permanece controversa.

Objetivo Avaliar se a mutação MTHFR C677T é mais frequente em mulheres inférteis, e se pode ser associada com a ocorrência de infertilidade na população brasileira.

Métodos Estudo de caso-controle, com avaliação de 130 mulheres com infertilidade atendidas em clínica privada no período de março de 2003 a março de 2005 (dados received

December 2, 2016

accepted

June 12, 2017

published online

August 28, 2017
DOI https://doi.org/

10.1055/s-0037-1606289.

ISSN 0100-7203.
Copyright (e 2017 by Thieme Revinter

Publicações Ltda, Rio de Janeiro, Brazil
License terms

(ㄷ) (i) $\ominus$ (5) 


\section{Palavras-chave}

- infertilidade

- trombofilia

- mutação MTHFR C677T previamente publicados) e 260 mulheres férteis atendidas no ambulatório de planejamento familiar de nossa instituição no período de abril de 2012 a março de 2013. Análise dos dados Foram utilizados os testes de Qui-quadrado e Exato de Fisher para o estudo da associação entre a presença da mutação MTHFR C677T e o antecedente de infertilidade.

Resultados A frequência da mutação foi de $58,5 \%$ nos casos $(n=76)$ e de $49,2 \%$ nos controles $(n=128)$. Dentre os casos, 13 apresentavam esta mutação em homozigose (10\%). Nos controles, a homozigose foi encontrada em 23 mulheres férteis (8,8\%). Estas diferenças não foram estatisticamente significativas.

Conclusões Este estudo sugere que a presença da mutação MTHFR C677T não constitui fator de risco para infertilidade, mesmo em casos de homozigose. Estudos complementares são necessários para ratificar se a investigação desta mutação deve ser considerada desnecessária em mulheres com infertilidade.

\section{Introduction}

The C677T mutation in the methylenetetrahydrofolate reductase (MTHFR) gene has been investigated for the past 20 years. However, the importance of this mutation as a risk factor for the occurrence of thrombosis remains controversial. Some authors consider it an inherited thrombophilic factor. ${ }^{1}$

In women who have difficulty conceiving, the possible causes of embryo implantation failure have been investigated, both in spontaneous cycles and in induced cycles in assisted reproduction. Among the various factors that may interfere with the implantation process, thrombophilic factors are considered to hamper fertility. ${ }^{2}$

A study conducted with a Brazilian population found a greater incidence of homozygous MTHFR mutations in Caucasian individuals (10\%) compared with Blacks $(1.45 \%)$ and Brazilian Native Indians (1.2\%). ${ }^{3}$ An analysis of the association between this mutation and hyperhomocysteinemia showed that among the Brazilian population, folic acid levels are the greatest determinants of plasma homocysteine. ${ }^{4}$

Over the past ten years, thrombophilias have been identified with increasing frequency in women submitted to repeat treatment cycles of in vitro fertilization (IVF) with failed embryo implantation when compared with fertile women. Azem et al ${ }^{5}$ conducted a case-control study analyzing hereditary thrombophilia factors in infertile, fertile and women with failed implantation. That study reported a high frequency of thrombophilia in the subgroup of women with implantation failure. Those authors suggested a negative effect of a state of hypercoagulability on embryo implantation. Similar results were reported by Grandone et al. ${ }^{6}$

Nevertheless, the relationship between thrombophilia, including the MTHFR C677T mutation, and infertility cannot be considered proven based on the level of scientific evidence from case-control studies conducted with limited sample sizes.

Studies were then conducted to investigate the presence of the MTHFR C677T mutation in infertile women and in women with failed implantation; however, the results are controversial. Some authors failed to identify inherited thrombophilia, including the MTHFR C677T mutation, as a risk factor for infertility, ${ }^{7,8}$ while others reported conflicting findings, particularly in women in whom embryo implantation had failed. ${ }^{9}$

In view of these data, we deemed pertinent to conduct the present study to clarify the importance of investigating the MTHFR C677T mutation in infertile women. The study was aimed at evaluating whether the MTHFR C677T mutation is more common in infertile women, and whether it constitutes a risk factor for the occurrence of infertility in the Brazilian population.

\section{Methods}

A case-control study was conducted with a sample of 390 women divided into 2 groups: a group of fertile women $(n=260)$ and a group of infertile women $(n=130)$.The frequency of the MTHFR C677T mutation was then determined for the two groups.

The infertile women were selected by reviewing the files of patients attending a private clinic between March 2003 and March 2005. ${ }^{10}$ All of the women were Caucasian and aged over 18 years, with primary and unexplained infertility. Male or tubal factors were excluded.

The control group was composed by healthy fertile women who were selected at the family planning clinic of our institution between April 2012 and March 2013. The inclusion criteria were: being Caucasian, having had at least 1 previous term delivery, age $\geq 18$ years old, and having no previous obstetric concerns, no history of liver or hematological diseases, nor infection.

The sample size was calculated using different sources based on the difference in the prevalence of thrombophilic factors between the infertile and fertile women. ${ }^{11,12}$ Considering a significance level of $5 \%$, a proportion of 2 fertile women for every infertile woman and a power of the test of $80 \%$, based on the formula developed by Pocock ${ }^{13}$ for the Chisquared test, a sample size of 390 women was calculated: 130 infertile women and 260 fertile women. 
The Chi-squared and Fisher exact tests were used in the statistical analysis.

\section{MTHFR Mutation Detection}

A venous blood sample $(5 \mathrm{~mL})$ was retrieved from each patient and quickly placed into sterile Vacutainer tubes (Becton, Dickinson and Company [BD], Franklin Lakes, NJ, US) containing ethylenediamine tetra acetic acid and then divided into sterile Eppendorf tubes (Eppendorf, Hamburg, Germany) and stored at $-80^{\circ} \mathrm{C}$ until it was time to perform the molecular study of the MTHFR polymorphisms. We extracted DNA from nucleated blood cells using a phenol chloroform method. ${ }^{14}$ The MTHFR polymorphisms were detected by polymerase chain reactionrapid fragment length polymorphism (PCR-RFLP) using the Hinfl restriction analysis of a 198-bp PCR-amplified fragment in the gene for MTHFR. ${ }^{15}$ The products of the Hinfl digestion were electrophoresed on $3 \%$ agarose gels. The normal allele with cytosine at position 677 (C677) formed an undigested fragment of $198 \mathrm{bp}$, while the mutant allele with thymine in position 677 (T677) formed fragments of 175 and $23 \mathrm{bp}$.

The Ethical Committee of another institution approved the study protocol under reference number 153 on July 13, 2009. All patients signed an informed consent form, and the ethical aspects were observed in accordance with the Declaration of Helsinki.

\section{Results}

The women selected for evaluation in the present study were all white, since this is the ethnic group in which the occurrence of thrombophilia is the highest. The mean age of the patients in the case group was $36 \pm 4.5$ years ( \pm standard deviation [SD]) compared with $34.2 \pm 8.1$ years for the fertile women. As for parity, $38 \%$ of the women in the fertile group had had 2 previous term deliveries, and $25 \%$ had had 3 or more children. Among the non-hormonal contraceptive methods used by the women in the control group, $71 \%$ used the TCu 380A intrauterine device (IUD). Regarding marital status, most of the fertile women (82\%) and all the women in the infertile group were in a stable union. In the group of infertile women, the mean time of infertility was $5 \pm 3.3$ years.

The MTHFR C677T mutation was found in $49.2 \%$ of the fertile women, and in $58.5 \%$ of the infertile women, a difference that was not statistically significant. The mutation was homozygous in $10 \%$ of the women in the case group (13 of the infertile women) and in $8.8 \%$ of the controls ( 23 of the fertile women). These results are shown in -Table 1.

Out of the 260 fertile women evaluated, 37 had a history of a previous spontaneous abortion. However, when the presence of the MTHFR mutation was investigated in this subgroup and in the subgroup of women who had suffered no previous pregnancy loss, no statistically significant difference was found (-Table $\mathbf{2}$ ).

\section{Discussion}

The results of the present study show a slightly higher frequency of the MTHFR C677T mutation in infertile women;
Table 1 MTHFR mutation in cases (infertile women) and controls (fertile women)

\begin{tabular}{|l|l|l|l|}
\hline & Cases & Controls & $p$ \\
\hline $\begin{array}{l}\text { Absence of } \\
\text { MTHFR mutation }\end{array}$ & $54(41.5 \%)$ & $132(50.8 \%)$ & 0.08 \\
\hline $\begin{array}{l}\text { Presence of } \\
\text { MTHFR mutation }\end{array}$ & $76(58.5 \%)$ & $128(49.2 \%)$ & \\
\hline $\begin{array}{l}\text { Heterozygous } \\
\text { MTHFR mutation }\end{array}$ & $63(48.5 \%)$ & $105(40.4 \%)$ & 0.22 \\
\hline $\begin{array}{l}\text { Homozygous } \\
\text { MTHFR mutation }\end{array}$ & $13(10 \%)$ & $23(8.8 \%)$ & \\
\hline
\end{tabular}

Abbreviation: MTHFR, methylenetetrahydrofolate reductase.

Table 2 Fertile women with and without a history of pregnancy loss

\begin{tabular}{|l|l|l|l|}
\hline $\begin{array}{l}\text { MTHFR } \\
\text { mutation }\end{array}$ & $\begin{array}{l}\text { No previous } \\
\text { pregnancy loss }\end{array}$ & $\begin{array}{l}\text { Previous } \\
\text { pregnancy loss }\end{array}$ & $p$ \\
\hline Present & $111(49.8 \%)$ & $17(45.9 \%)$ & 0.66 \\
\hline Absent & $112(50.2 \%)$ & $20(54.1 \%)$ & \\
\hline
\end{tabular}

Abbreviation: MTHFR, methylenetetrahydrofolate reductase.

however, this difference was not statistically significant. These findings are corroborated by the results of previous studies that also failed to find a greater frequency of inherited thrombophilia in infertile women.

In some case-control studies analyzed, which compared women with infertility of no apparent cause and fertile women, inherited thrombophilia was investigated. Those results are in agreement with the findings of the present study in relation to the MTHFR C677T gene mutation. ${ }^{8,16}$

Moreover, in 2010, Sharif and Ghunaim ${ }^{17}$ conducted a prospective cohort study in which 273 cases of implantation failure were analyzed. That study emphasizes the importance of micro-thrombosis at the implantation site as a factor that prevents trophoblastic invasion and consequently embryo implantation. Since there was no subgroup with implantation failure in the present study, it is impossible to make any affirmations regarding the association between this mutation and women with implantation failure.

In 2016, Patounakis et al ${ }^{18}$ conducted a prospective cohort to determine if thrombophilic single nucleotide polymorphisms (SNPs) affect outcomes in IVF treatments, and investigated the MTHFR (C677T and A1298C) mutations. They did not find any association between the MTHFR mutation and the IVF outcomes. They did not recommend this investigation for initial screening. Those results are in agreement with our findings in relation to the MTHFR C677T gene mutation.

The MTHFR C677T mutation has been associated with adverse obstetric events and with the risk of recurrent pregnancy loss. ${ }^{1,19,20}$ In our study, this mutation was present in $49.2 \%$ of the fertile women, and it was homozygous in $8.8 \%$ of them. This significant frequency in fertile and healthy women suggests that this mutation is probably not responsible for 
causing adverse effects in pregnancy. Nevertheless, that was not the objective of this study; furthermore, the mutation was homozygous in only a small proportion of the sample evaluated (in $8.8 \%$ of the controls). In 2006, Ren and Wang ${ }^{21}$ conducted a meta-analysis and found no association between the MTHFR mutation and recurrent pregnancy loss. Some studies suggested the role of the MTHFR C677T polymorphism in certain diseases (vascular diseases, cancers, neurologic diseases, diabetes, psoriasis, etc.). However, an interpretation of such results is compromised by the heterogeneity of the population sample and the small case series. ${ }^{22}$

Recently, Boas et $\mathrm{al}^{23}$ evaluated the polymorphisms in genes involved in folate metabolism and their association with recurrent pregnancy loss in the Brazilian population. In the present study, no evidence was found of any association between the MTHFR C677T mutation and recurrent pregnancy loss.

The MTHFR mutation appears to be common in the general population, but its clinical implication does not appear evident in the reviewed literature. Therefore, MTHFR screening is not indicated for the asymptomatic general population, and its clinical expression is uncertain. ${ }^{24}$

Based on these findings and on the literature evaluated, it is our opinion that the MTHFR C677T mutation is not associated with infertility, and we would not recommend its investigation in this population. The investigation in infertile women is considered unnecessary.

\section{Funding}

Fundação de Amparo à Pesquisa do Estado de São Paulo (Fapesp) provided financial support under grant number 2010/09615-0.

\section{Role of Funding Source}

The sponsor had no involvement in the study design, in the collection, analysis or interpretation of data, in the writing of the report, or in the decision to submit the article for publication.

\section{Conflict of Interests}

Authors declare no conflict of interest.

\section{References}

1 Naidu CA, Moodley J, Pegoraro R, Rom L. Methylenetetrahydrofolate (MTHFR) reductase gene polymorphism in African women with abruptio placentae. Eur J Obstet Gynecol Reprod Biol 2007; 132(02):241-243

2 Simon A, Laufer N. Assessment and treatment of repeated implantation failure (RIF). J Assist Reprod Genet 2012;29(11):1227-1239

3 Arruda VR, Siqueira LH, Gonçalves MS, et al. Prevalence of the mutation $\mathrm{C} 677->\mathrm{T}$ in the methylene tetrahydrofolate reductase gene among distinct ethnic groups in Brazil. Am J Med Genet 1998;78(04):332-335

4 Aléssio AC, Annichino-Bizzacchi JM, Bydlowski SP, Eberlin MN, Vellasco AP, Höehr NF. Polymorphisms in the methylenetetrahy- drofolate reductase and methionine synthase reductase genes and homocysteine levels in Brazilian children. Am J Med Genet A 2004;128A(03):256-260

5 Azem F, Many A, Ben Ami I, et al. Increased rates of thrombophilia in women with repeated IVF failures. Hum Reprod 2004;19(02): 368-370

6 Grandone E, Colaizzo D, Lo Bue A, Checola MG, Cittadini E, Margaglione $\mathrm{M}$. Inherited thrombophilia and in vitro fertilization implantation failure. Fertil Steril 2001;76(01):201-202

7 Vaquero E, Lazzarin N, Caserta D, et al. Diagnostic evaluation of women experiencing repeated in vitro fertilization failure. Eur J Obstet Gynecol Reprod Biol 2006;125(01):79-84

8 Casadei L, Puca F, Privitera L, Zamaro V, Emidi E. Inherited thrombophilia in infertile women: implication in unexplained infertility. Fertil Steril 2010;94(02):755-757

9 Safdarian L, Najmi Z, Aleyasin A, Aghahosseini M, Rashidi M, Asadollah S. Recurrent IVF failure and hereditary thrombophilia. Iran J Reprod Med 2014;12(07):467-470

10 Soligo AGS, Barini R, Carvalho ECC, Annichino-Bizzacchi J. [Prevalence of thrombophilic factors in infertile women]. Rev Bras Ginecol Obstet 2007;29(05):235-240 Portuguese

11 Martinelli I, Taioli E, Ragni G, et al. Embryo implantation after assisted reproductive procedures and maternal thrombophilia. Haematologica 2003;88(07):789-793

12 Qublan HS, Eid SS, Ababneh HA, et al. Acquired and inherited thrombophilia: implication in recurrent IVF and embryo transfer failure. Hum Reprod 2006;21(10):2694-2698

13 Pocock SJ. Clinical trials: a practical approach. 5th ed. Chichester: John Wiley \& Sons; 1987

14 Ausubel FM, Brent R, Kingston RE, et al. Current protocols in molecular biology. Chichester: John Wiley \& Sons; 1987

15 Frosst P, Blom HJ, Milos R, et al. A candidate genetic risk factor for vascular disease: a common mutation in methylenetetrahydrofolate reductase. Nat Genet 1995;10(01):111-113

16 Marci R, Lisi F, Soave I, et al. Impact of $677 \mathrm{C}>\mathrm{T}$ mutation of the 5,10-methylenetetrahydrofolate reductase on IVF outcome: is screening necessary for all infertile women? Genet Test Mol Biomarkers 2012;16(09):1011-1014

17 Sharif KW, Ghunaim S. Management of 273 cases of recurrent implantation failure: results of a combined evidence-based protocol. Reprod Biomed Online 2010;21(03):373-380

18 Patounakis G, Bergh E, Forman EJ, et al. Multiple thrombophilic single nucleotide polymorphisms lack a significant effect on outcomes in fresh IVF cycles: an analysis of 1717 patients. J Assist Reprod Genet 2016;33(01):67-73

19 Cao Y, Xu J, Zhang Z, et al. Association study between methylenetetrahydrofolate reductase polymorphisms and unexplained recurrent pregnancy loss: a meta-analysis. Gene 2013;514(02): 105-111

20 Zhu L. Polymorphisms in the methylene tetrahydrofolate reductase and methionine synthase reductase genes and their correlation with unexplained recurrent spontaneous abortion susceptibility. Genet Mol Res 2015;14(03):8500-8508

21 Ren A, Wang J. Methylenetetrahydrofolate reductase C677T polymorphism and the risk of unexplained recurrent pregnancy loss: a meta-analysis. Fertil Steril 2006;86(06):1716-1722

22 Liew SC, Gupta ED. Methylenetetrahydrofolate reductase (MTHFR) C677T polymorphism: epidemiology, metabolism and the associated diseases. Eur J Med Genet 2015;58(01):1-10

23 Boas WV, Gonçalves RO, Costa OL, Gonçalves MS. Metabolism and gene polymorphisms of the folate pathway in Brazilian with history of recurrent abortion. Rev Bras Ginecol Obstet 2015;37 (02):71-76

24 Long S, Goldblatt J. MTHFR genetic testing: Controversy and clinical implications. Aust Fam Physician 2016;45(04):237-240 